\title{
Effects of anoxia and sulphide on populations of Cletocamptus confluens (Copepoda, Harpacticoida)
}

\author{
Kay Vopel ${ }^{1, *}$, Jens Dehmlow ${ }^{2}$, Maria Johansson ${ }^{3}$, Günter Arlt ${ }^{2}$ \\ 'Alfred Wegener Institute for Polar and Marine Research, Columbus Center, D-27568 Bremerhaven, Germany \\ ${ }^{2}$ University of Rostock, Dept of Biology, Marine Biology Unit, Freiligrathstr. 7/8, D-18051 Rostock, Germany \\ ${ }^{3}$ University of Uppsala, Department of Biology, S-7512 Uppsala, Sweden
}

\begin{abstract}
The harpacticoid copepod Cletocamptus confluens (Schmeil 1894), which inhabits mud pools of sheltered shallow water bays, was studied to analyse its ability to survive in anoxia and sulphidic anoxia, its normoxic oxygen consumption, and its glycogen content. In addition, the impact of anoxia and sulphide on the viability of eggs and the time-scale of development of nauplii and copepodids was investigated. All measurements were carried out on laboratory-reared specimens. The mean survival rate of non-gravid females did not drop below $96^{\circ}$ after $96 \mathrm{~h}$ of exposure to both anoxia and sulphidic anoxia. Males and egg sac bearing females showed lower survival rates. The weight-specific glycogen content of non-gravid females $\left(891.8 \pm 51.0 \mu \mathrm{mol}\right.$ glycosyl units $\mathrm{g}^{-1} \mathrm{dw}$ ) was more than twice as high as that of males ( $404.3 \pm 31.4 \mu \mathrm{mol}$ glycosyl units $\mathrm{g}^{-1} \mathrm{dw}$ ) and decreased to about $63 \%$ during $96 \mathrm{~h}$ exposure to anoxic and anoxic/sulphidic conditions. The weight-specific oxygen consumption of males and non-gravid females amounted to $223.8 \pm 61.7$ and $59.7 \pm 8.1 \mu \mathrm{mol} \mathrm{O} 2 \mathrm{~g}^{-1} \mathrm{dw} \mathrm{h}^{-1}$, respectively. The viability of eggs was not affected during $96 \mathrm{~h}$ of anoxia and sulphidic anoxia, and hatching of nauplii was delayed for the period of exposure. The developmental time of nauplii and copepodids from eggs incubated in anoxic or anoxic/sulphidic conditions did not differ from that of the normoxic controls. Sex-specific responses to anoxia and possible consequences for population dynamics of $C$. confluens are discussed.
\end{abstract}

KEY WORDS: Meiofauna Copepoda - Harpacticoida Cletocamptus confluens - Glycogen - Respiration - Reproduction $\cdot$ Development $\cdot$ Sulphide $\cdot$ Brackish water

\section{INTRODUCTION}

The chemical environment in semi-isolated mud pools of the southwest Baltic shore is defined by periods of intense sulphide production. Sulphide not only provides energy for microbial metabolism, but acts as a potent inhibitor of cytochrome $c$ oxidase and is thus toxic for most aerobic metazoans (National Research Council 1979, Bagarinao 1992, Grieshaber \& Völkel 1998). Meiofauna colonising the interface between the pools' mud and stagnant bottom water are exposed to steep and temporally variable gradients of sulphide. oxygen and $\mathrm{pH}$. The transition zone between oxygen and sulphide (chemocline) is often restricted to sediment strata of some $\mu \mathrm{m}$ thickness and its position

•E-mail: kvopel@awi-bremerhaven.de changes diurnally in response to the light cycle. During the night, sulphide can diffuse from the sediment into the overlying water turning the conditions anoxic. When solar radiation is sufficiently intense, the top sediment layer and the bottom water become oxic again due to oxygenic photosynthesis and light-driven sulphide oxidation by phototrophic bacteria. A frequent or regular shift between oxic and anoxic sulphidic conditions is a common situation for mud dwelling meiofauna (Hansen et al. 1978, Jørgensen et al. 1979, Revsbech et al. 1983)

During the summer months, however, high temperature enhances the intensity of sulphate reduction and benthic respiration. Consequently, the oxygen-combining capacity of the mud exceeds the rate at which oxygen is supplied by benthic photosynthesis and diffusion from the bottom water. In this time, the entire 
sediment and the bottom water can remain anoxic and sulphidic for several days. Such long-lasting anoxic periods can be important in structuring benthic communities of semi-isolated pools. The mud pools are known to have been successfully colonised by only a few meiofaunal species, among them the harpacticoid copepod Cletocamptus confluens (Vopel et al. 1996). This species has already frequently been reported from sulphidic environments. Schäfer (1936) and Lasserre et al. (1975), for instance, found C. confluens in small brackish water mud pools and in semienclosed lagoons, respectively. According to Escaravage \& Castel (1990), this species, together with nematodes and insect larvae, occurred in high abundance in a lagoon ecosystem. Furthermore, $C$. confluens was reported to predominate in isolated locations by Castel (1992).

The aim of the present laboratory study was to clarify how populations of Cletocamptus confluens cope with the long-lasting periods of anoxia and exposure to the high sulphide concentrations which frequently occur in these biotopes. Assuming a stagnation period of several days, experiments were designed to test whether and to what extent a $96 \mathrm{~h}$ period of anoxia combined with a high sulphide concentration would affect adult males and females as well as the development of newly spawned eggs.

\section{MATERIAL AND METHODS}

Copepods. All experiments were performed with Cletocamptus confluens specimens taken from laboratory cultures. Copepods were reared in microcosms kept in an incubator which was set to $18 \mathrm{~h}$ of illumination at a temperature of $20^{\circ} \mathrm{C}$, and $6 \mathrm{~h}$ of darkness at a temperature of $18^{\circ} \mathrm{C}$. The microcosms were established in glass cylinders (diameter: $6 \mathrm{~cm}$, length: $23 \mathrm{~cm}$ ) filled with $1 / 3$ original mud and $2 / 3$ brackish seawater (salinity 10 PSU). Altogether, 8389 females and 956 males of $C$. confluens were used

Exposure to anoxia and sulphide. The harpacticoid copepods were exposed in natural seawater $(0.2 \mu \mathrm{m}$ filtered, salinity $10 \mathrm{PSU}$, temperature $20^{\circ} \mathrm{C}$ ) adjusted to a $\mathrm{pH}$ of $6.5,7.5$ or 9.5 (50 mM HEPES buffer) under darkness and without food in stoppered flasks (volume $\approx 17 \mathrm{ml}, \mathrm{pH} 7.5$ ) or in a flow-through system (volume $\approx 2.2 \mathrm{ml}$, flow rate $=0.06 \mathrm{ml} \mathrm{min}^{-1}, \mathrm{pH} 6.5$ and 9.5). The concentration of sulphide was adjusted by adding sodium sulphide to water which had previously been aerated with nitrogen and subsequently degassed under vacuum in an ultrasonic bath. Prior to the experiments, the buffering capacity of the HEPES system $\left(\mathrm{p} K_{\mathrm{S}}=7.55\right)$ was tested over the experimental range of $\mathrm{pH}$ values using natural seawater and different buffer concentrations. At a HEPES concentration of $50 \mathrm{mmol}$ $\mathrm{l}^{-1}$ the $\mathrm{pH}$ shift per addition of $100 \mu \mathrm{mol} \mathrm{\textrm {I } ^ { - 1 }}$ sulphide amounted to 0.034 and 0.066 at the lowest and the highest $\mathrm{pH}$ values, respectively. These values were taken into account when adjusting the $\mathrm{pH}$ for exposure experiments. Sulphide determination was carried out photometrically (Gilboa-Garber 1971). Concentrations are given as total reduced sulphur concentration $\left[\mathrm{S}_{\mathrm{T}}\right]$ in the $\mathrm{pH}$-dependent equilibrium $\mathrm{H}_{2} \mathrm{~S} \leftrightarrow \mathrm{HS}^{-}+\mathrm{H}^{+} \leftrightarrow$ $\mathrm{S}^{2-}+2 \mathrm{H}^{+}$. The initial concentration of sulphide in the stoppered flasks decreased within 24 h from $436 \pm$ 18 to $372 \pm 27 \mu \mathrm{mol} \mathrm{l} \mathrm{l}^{-1}$. Within the $96 \mathrm{~h}$ incubation period, the sulphide concentration decreased from $439 \pm 34$ to $338 \pm 78 \mu \mathrm{mol} \mathrm{l} \mathrm{l}^{-1}$. The sulphide concentration of the water used for the flow-through experiments decreased by a maximum of $0.5 \mathrm{mmol} \mathrm{l}^{-1}$ (96 h). All copepods were adapted to the incubation conditions by transferring them into filtered brackish water with the experimental $\mathrm{pH} 24 \mathrm{~h}$ before the exposure experiments.

Measurement of oxygen consumption. The individual oxygen consumption of non-gravid females (11 specimens) and males ( 6 specimens) was measured in a microrespirator using a modification of the Cartesian diver principle (Holter 1943, Zeuthen 1950, Klekowski 1971). Prior to the measurements of oxygen consumption (as well as of glycogen content, see 'Determination of glycogen'), the specimens were transferred to artificial seawater, to which penicillin/streptomycin $1500 \mathrm{U}$ penicillin and $0.5 \mathrm{mg} \mathrm{ml}^{-1}$ streptomycin) had been added. The experimental temperature was kept at $20 \pm$ $0.01^{\circ} \mathrm{C}$. All respiration measurements were carried out in normoxic filtered brackish water $(0.2 \mu \mathrm{m}$ pore size) at a salinity of 10 PSU. The oxygen consumption was calculated according to Klekowski (1971):

$$
\Delta V_{\mathrm{O}_{2}}=\left(V_{\mathrm{g}} \cdot \Delta P \cdot 273\right)\left(P_{0} \cdot T\right)^{-1}
$$

where $\Delta V_{\mathrm{O}_{2}}$ : volume of consumed oxygen within time measured $(\mu l), V_{\mathrm{g}}$ : volume of air bubble inside the diver $(\mu l), \Delta P$ : difference of pressures necessary to keep the diver at a defined height prior and subsequent to a measurement (mm Brodie's fluid), $P_{0}$ : pressure in the system (mm Brodie's fluid), and $T$ : temperature in the system $\left({ }^{\circ} \mathrm{C}\right)$. Previously determined means of dry weight (see 'Body length and dry weight') were used for calculation of the weight-specific oxygen consumption.

Determination of glycogen. In each case, 5 groups of 150 individuals served for the determination of the glycogen content of males and non-gravid females. Analyses were carried out immediately after the copepods had been taken from the cultures. An additional 4500 non-gravid females were exposed for 24 and $96 \mathrm{~h}$ to normoxia, anoxia and sulphidic anoxia $\left(\left[\mathrm{S}_{\mathrm{T}}\right] \approx\right.$ $430 \mu \mathrm{mol} \mathrm{l}^{-1}$ ) at a $\mathrm{pH}$ of 7.5 and thereafter analysed for their glycogen content. Glycogen extraction, enzy- 
matic hydrolysis and glycogen determination were carried out according to Schöttler et al. (1990) and Bergmeyer (1984). Some modifications were necessary due to the small size of the copepods: they were rinsed with artificial seawater (salinity $10 \mathrm{PSU}, \mathrm{pH}$ 7.5), dried with filter paper, and transferred to $0.2 \mathrm{ml}$ ice-cooled $\mathrm{KOH}(30 \%)$. After a $10 \mathrm{~s}$ homogenisation, samples were boiled in a water-bath for $1 \mathrm{~h}$. The material was centrifuged $(5400 \times g)$ for $10 \mathrm{~min}$ and the supernatant decanted. Saturated $\mathrm{Na}_{2} \mathrm{SO}_{4}(0.04 \mathrm{ml})$ and $1 \mathrm{ml}$ absolute ethanol were added. The mixture was boiled for another $10 \mathrm{~min}$ and subsequently stored at $4^{\circ} \mathrm{C}$ for $12 \mathrm{~h}$. After centrifugation $(5400 \times g, 10 \mathrm{~min})$ the supernatant was discarded and the pellet redissolved in acetate buffer $(0.8 \mathrm{ml}, 1.0 \mathrm{M}, \mathrm{pH} 4.8)$. Acetate buffer $(0.2 \mathrm{ml}, 0.2 \mathrm{M}, \mathrm{pH} \mathrm{4.8)}$ and $25 \mu \mathrm{l}$ amyloglucosidase were added and the sample incubated for $2.5 \mathrm{~h}$ at $40^{\circ} \mathrm{C}$. Enzyme hydrolysis was stopped by boiling and the sample was centrifuged at $3400 \times g$ for $10 \mathrm{~min}$. Tissue extract and $0.5 \mathrm{mg} \mathrm{ml}^{-1}$ glucose-6-phosphate dehydrogenase were added to the glucose buffer which contained $400 \mathrm{mM}$ triethanolamine/ $\mathrm{HCl}, 5 \mathrm{mM} \mathrm{Mg}{ }^{2+}$ acetate, $0.8 \mathrm{mM}$ NADP and $0.7 \mathrm{mM}$ ATP. The enzymatic hydrolysis was started by adding hexokinase (1 $\mathrm{mg} \mathrm{ml}^{-1}$ ). Photometrical measurements were carried out at $340 \mathrm{~nm}$.

Influence of anoxia and sulphide on hatching of nauplii. A total of 180 (90 per treatment) egg sac bearing females were exposed to anoxia or anoxia/sulphide $\left(1.5 \mathrm{mmol}^{-1}\right)$ for $96 \mathrm{~h}$ at a $\mathrm{pH}$ of 6.5 and a temperature of $20^{\circ} \mathrm{C}$. They were then removed and each individual placed into a dish of normoxic water. The hatching of nauplii within the incubation time and during the following 6 d was recorded. An additional 90 egg sac bearing females, kept in normoxic water for the entire period, served às a control group.

Developmental time. For the determination of the developmental time of Cletocamptus confluens, $37 \mathrm{egg}$ sac carrying females were transferred into separate petri dishes containing normoxic seawater (salinity 10 PSU). Detritus was added and dishes were stored in an incubator $\left(16 \mathrm{~h}\right.$ at $20^{\circ} \mathrm{C}$ and light, $8 \mathrm{~h}$ at $18^{\circ} \mathrm{C}$ and darkness). The hatching of nauplii and appearance of copepodids or adults were checked every $24 \mathrm{~h}$. The same observations were carried out with the egg sac bearing females exposed to anoxia, sulphide and normoxia after the incubation period was completed (see above).

Body length and dry weight. Body length was measured by determining the distance between the end of furcal rami (without setae) and the tip of rostrum. For this purpose, 68 adult males and 34 adult females were narcotised by transferring them into seawater to which $\mathrm{MgCl}_{2}$ had been added. The individual dry weight of both sexes was calculated by weighing 20 groups, each containing 10 males or non-gravid females. Previously, all copepods had been rinsed several times in filtered brackish water $(0.2 \mu \mathrm{m}$ pore size $)$ and kept there for at least $3 \mathrm{~h}$. Thereafter, the copepods were pooled into groups of 10 and pipetted onto small sieves, rinsed with distilled water, and then dried at $50^{\circ} \mathrm{C}$ for $24 \mathrm{~h}$.

Statistics. Data are given as means \pm standard deviations. The significance of differences was analysed using the non-parametric $U$-test of Mann and Whitney at a significance level of $5 \%$ (Sachs 1992).

\section{RESULTS}

\section{Survival under anoxic and sulphidic conditions}

A total of 3000 non-gravid females (150 specimens in each of 5 replicates) were incubated in stoppered flasks under anoxic and anoxic/sulphidic conditions at $\mathrm{pH} 7.5$ for 24 and $96 \mathrm{~h}$. A mean of $97.4 \pm 0.2$ (24 h) and $99.2 \pm 0.5 \%$ (96 h) of the copepods survived the anoxic conditions. After sulphide exposure, survival rates of $96.6 \pm 1.4$ and $97.5 \pm 2.5 \%$ were obtained, respectively.

An additional 2560 non-gravid females were tested in a flow-through system at a significantly higher sulphide concentration ( 1.9 to $2.7 \mathrm{mmol} \mathrm{l}^{-1}$ ) and a $\mathrm{pH}$ of 9.5 and 6.5 for 24 and 96 h (Table 1). Despite the high sulphide concentrations and extreme $\mathrm{pH}$ values, the survival rates never dropped below $95 \%$. The majority of the copepods survived the experimental exposure motionless and became active again a few minutes after being transferred back to normoxic water.

In further 96 h tests, males and egg sac bearing females were exposed at $\mathrm{pH} 6.5$, only, in order to keep $\left[\mathrm{H}_{2} \mathrm{~S}\right]$ quantities as high as possible. In contrast to nongravid females, they showed a significantly lower ability to survive anoxia and sulphidic anoxia: the survival rates of egg sac bearing females were 50 and $66 \%$, respectively. Males were more sensitive. Only 11\% survived sulphidic anoxia and $9 \%$ exposure to anoxia, the differences being not significant (Table 1).

\section{Impact of anoxia and sulphide on hatching and development}

After 96 h exposures, egg sac bearing females were transferred into normoxic water and observed for a further $6 \mathrm{~d}$ for the hatching of nauplii (Fig 1). In the case of the normoxic controls, nauplii hatched from all egg sacs within the first $5 \mathrm{~d}$. The nauplii of anoxically incubated females hatched within $5 \mathrm{~d}$ of the copepods being re-transferred to normoxic water. Here, $93 \%$ of egg sacs tested released nauplii. Hatching was also found to be delayed in the anoxic/sulphidic incubation. 


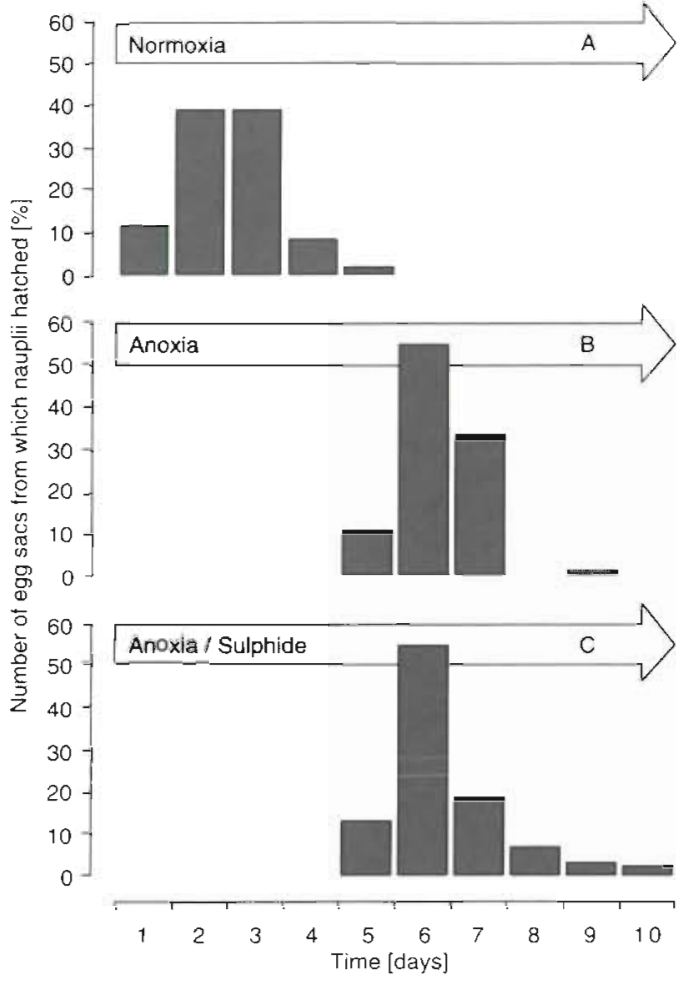

Fig. 1. Cletocamptus confluens. Effect of anoxia and sulphide on hatching. (A) Females with new-spawn egg sacs were observed under normoxic conditions for the entire period of $10 \mathrm{~d}$ (control group). ( $\mathrm{B}, \mathrm{C})$ Two groups of egg sac bearing females were exposed for $4 \mathrm{~d}$ (grey part of arrows) to anoxia and to anoxia combined with sulphide $\left(1.5 \mathrm{mmol} \mathrm{I}^{-1}\right)$, respectively. Afterwards they were removed to normoxic water (white part of arrows). Water temperature: $20^{\circ} \mathrm{C}_{\mathrm{i}} \mathrm{pH} 6.5$; salinity: 10 PSU

In such situations, nauplii hatched from $90 \%$ of all egg sacs tested. In fact, nauplii hatched successfully even when the females died during the experiment.

The time-scale of development from nauplii to the adult stages was investigated using 37 egg sac bearing females. First copepodids were observed $9.5 \pm 1.4 \mathrm{~d}$ and adults $16.1 \pm 1.9 \mathrm{~d}$ after the hatching of nauplii. The subsequent development of nauplii which hatched from anoxia and sulphidic anoxia exposed egg sacs (see above) did not differ significantly as compared to the normoxic control in the time between hatching and the first copepodid and adult stages (Fig. 2). In the anoxic treatments, first copepodids appeared at $8.5 \pm 0.9 \mathrm{~d}$ and adults at $16.3 \pm 1.0 \mathrm{~d}$ after nauplii hatched. The sulphidic treatment yielded the first copepodids within $9.3 \pm 1.4 \mathrm{~d}$ and adults at $18.8 \pm 1.5 \mathrm{~d}$ after hatching. Nauplii which hatched from eggs incubated under normoxia (control group) developed to the first copepodid stage within $10.3 \pm 1.0 \mathrm{~d}$ and the first adult appeared after. $17.5 \pm 0.7 \mathrm{~d}$
Table 1 Cletocamptus confluens. Survival rate after 24 and $96 \mathrm{~h}$ exposure to anoxia and sulphide/anoxia (mean values \pm SD). Copepods were kept in darkness under starvation conditions in a flow-through incubator set to a temperature of $20^{\circ} \mathrm{C}$ and a salinity of 10 PSU

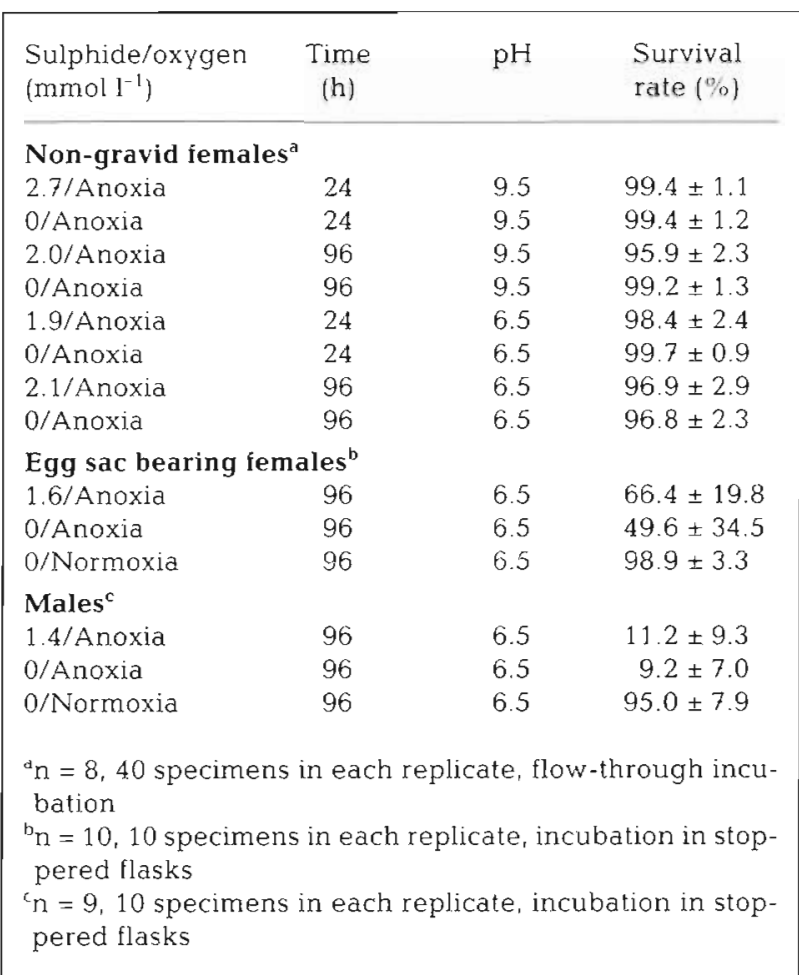

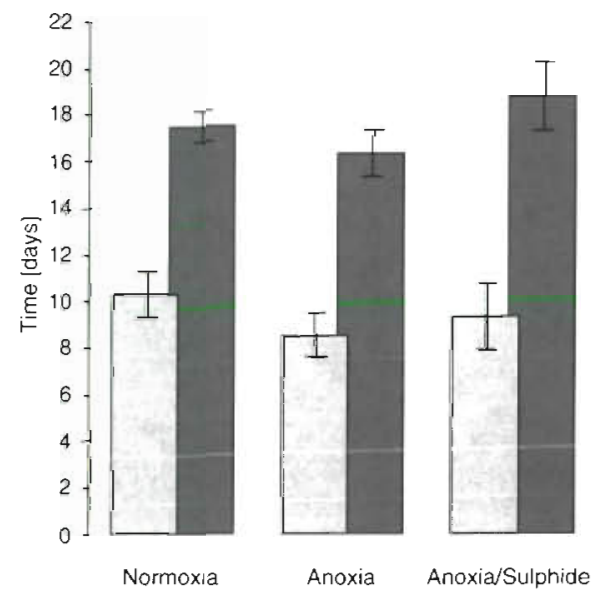

Fig. 2. Cletocamptus confluens. Time of development (mean values \pm SD) for nauplii hatched from egg sacs incubated in normoxic, anoxic and anoxic/sulphidic conditions. They were treated for $96 \mathrm{~h}$ at $10 \mathrm{PSU}$ and $20^{\circ} \mathrm{C}(\mathrm{n}=9)$ and observed over the incubation time and the following days for hatch of nauplii. Day of appearance of first copepodids and adults after hatching of nauplii for each treatment is shown. Light-grey bars indicate appearance of first copepodid stage (CI); darkgrey bars represent the appearance of first adults within the treatment 


\section{Body length and dry weight}

Adult males reached a body length of $600 \pm 63 \mu \mathrm{m}$ $(\mathrm{n}=68)$ and a dry weight of $1.2 \pm 0.1 \mu \mathrm{g}(\mathrm{n}=20)$. The mean body length of adult non-gravid females was $588 \pm 49 \mu \mathrm{m}(\mathrm{n}=34)$ and the dry weight was $2.1 \pm$ $0.3 \mu \mathrm{g}(\mathrm{n}=20)$.

\section{Oxygen consumption at normoxia}

On average, adult non-gravid females consumed $2.81 \pm 0.38 \mathrm{nl} \mathrm{O}_{2} \mathrm{~h}^{-1}$. Adult males had a markedly higher respiration rate of $6.02 \pm 1.66 \mathrm{nl} \mathrm{O}_{2} \mathrm{~h}^{-1}$. Considering the mean dry weight of non-gravid females and males, the following respiration rates were obtained: non-gravid females, $59.70 \pm 8.07 \mu \mathrm{mol} \mathrm{O}_{2} \mathrm{~g}^{-1} \mathrm{dw} \mathrm{h} \mathrm{h}^{-1}$; males, $223.82 \pm 61.72 \mu \mathrm{mol} \mathrm{O}_{2} \mathrm{~g}^{-1} \mathrm{dw} \mathrm{h}^{-1}$.

\section{Glycogen depletion}

Non-gravid female Cletocamptus confluens taken directly from the cultures (control) had a mean glycogen content of $891.8 \pm 51.0 \mu \mathrm{mol}$ glycosyl units $\mathrm{g}^{-1} \mathrm{dw}$. The tissue glycogen content of males was $404.3 \pm$ $31.4 \mu \mathrm{mol}$ glycosyl units $\mathrm{g}^{-1} \mathrm{dw}$. Non-gravid females starved under normoxic conditions for $96 \mathrm{~h}$ contained less glycogen $\left(725.8 \pm 43.5 \mu \mathrm{mol}\right.$ glycosyl units $\left.\mathrm{g}^{-1} \mathrm{dw}\right)$ compared with control levels and more glycogen than copepds exposed to anoxia (565.3 $\pm 45.4 \mu \mathrm{mol}$ glycosyl units $\left.\mathrm{g}^{-1} \mathrm{dw}\right)$ and to sulphidic anoxia $(568.5 \pm 32.3 \mu \mathrm{mol}$ glycosyl units $\mathrm{g}^{-1} \mathrm{dw}$ ). There were no significant differences between glycogen levels after anoxia and sulphidic anoxia exposures irrespective of whether copepods had been exposed for 24 or $96 \mathrm{~h}$ (Fig. 3).

\section{DISCUSSION}

In nature, the harpacticoids tested are exposed not only to fluctuating sulphide concentrations, but also to varying $\mathrm{pH}$. In order to account for higher concentrations of the most relevant sulphide form $\mathrm{H}_{2} \mathrm{~S}$, but also HS $^{-}$and $\mathrm{S}_{\mathrm{n}}^{2-}$, our exposure experiments with nongravid females of Cletocamptus confluens were carried out over a wide range of $\mathrm{pH}$. These experiments, however, did not show any significant mortality or differences as a result of $\mathrm{pH}$. Non-gravid females were able to survive $96 \mathrm{~h}$ of exposure to anoxia and anoxia combined with extremely high sulphide concentrations, regardless whether the $\mathrm{pH}$ was $6.5,7.5$ or 9.5 . Within the range of conditions examined there seems to exist no lethal effect of anoxia and anoxia combined with sulphide. Egg sac bearing female and male $C$.

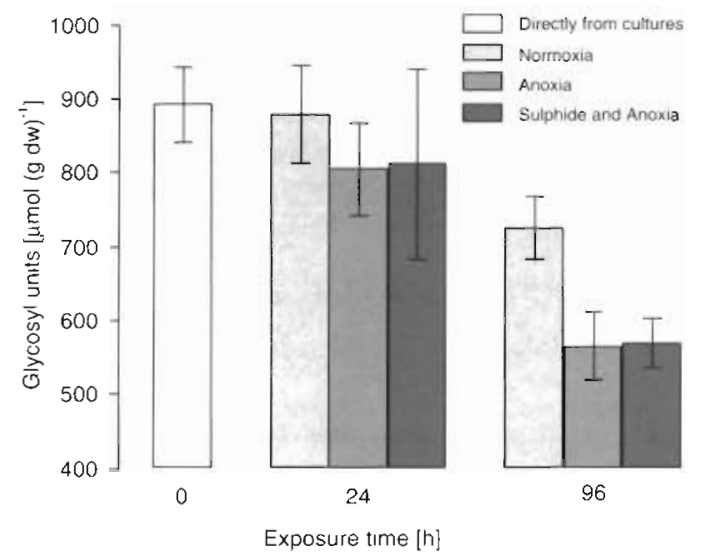

Fig. 3. Cletocamptus confluens. Glycogen content (mean values $\pm S D ; n=5$ ) of non-gravid females after 24 and $96 \mathrm{~h}$ exposure to normoxia, anoxia and sulphide $\left[\mathrm{S}_{\mathrm{T}}\right] \approx 430 \mu \mathrm{mol} \mathrm{l}^{-1}$, $\mathrm{pH} 7.5,20^{\circ} \mathrm{C}$ ) in comparison with the glycogen content of those taken directly from cultures (each replicate with 150 females)

confluens were tested only at pH 6.5, thereby keeping the concentration of undissociated hydrogen sulphide $\left(\mathrm{H}_{2} \mathrm{~S}\right)$ as high as possible. Again, there were no significant differences in the ability to survive anoxic and anoxic/sulphidic exposures. Male $C$. confluens were less resistant than egg sac bearing and non-gravid females. A similar sex-specific response has been shown by Tinson \& Laybourn-Parry (1985). The authors found female cyclopoid copepods to be more tolerant of anoxia than males. Differences between male and female harpacticoids were also found with respect to the effects of rotenone as well as of PCB (polychlorinated biphenyl) and PAH (polycyclic aromatic hydrocarbon) contaminations (Naess 1991, Di Pinto et al. 1993, Carman et al. 1995, Carman \& Todaro 1996).

\section{Survival under anoxia and sulphide}

Species colonising sulphidic sediments possess strategies to limit sulphide toxicity and to cope with anoxia, e.g. several internal and peripheral mechanisms for sulphide detoxification and a high anaerobic capacity (e.g. Somero et al. 1989, Vetter et al. 1991, Vismann 1991, Völkel \& Grieshaber 1992, 1994, Grieshaber et al. 1994). Powell (1989) postulated that for meiofauna, due to their small size, a sulphide detoxification system running at physiologically reasonable rates cannot maintain the internal sulphide concentration below the toxic level. Therefore, thiobiotic meiofauna are inferred to be sulphide-insensitive. Possible adaptations are believed to include variation in shape, distribution and metabolic capacity of mitochondria, and the modification of cellular $\mathrm{pH}$ and tis- 
sue diffusion coefficient (Powell 1989). Although nothing is known about the diffusion efficiency of sulphide through the exoskeleton of Cletocamptus confluens, one can expect that a $96 \mathrm{~h}$ exposure is sufficient to attain an equilibrium between internal and external sulphide concentrations. According to Jahn et al. (1996), the meiobenthic ostracod Cyprideis torosa (Jones 1850) is not able to maintain a low internal sulphide level when exposed to high sulphide concentration for periods longer than $2 \mathrm{~h}$. In spite of its ability to oxidise penetrating sulphide into non-toxic thiosulphate and sulphite, and valve closure, which lowers the apparent diffusion coefficient, the sulphide concentration in the tissues increased. Considering the facts that $C$. confluens does not possess a valve, that they were exposed to strictly anoxic conditions and that their body length is only about $600 \mu \mathrm{m}$ (smaller than $C$. torosa), one would expect that the equilibrium of the sulphide concentration inside and outside was achieved shortly after transfer to the incubation medium. Sulphide rapidly enters the tissues via diffusion and inhibits aerobic respiration. Since in nature sulphide affects $C$. confluens under anoxia, aerobic metabolism is impossible anyway and the inhibition of the cytochrome coxidase should be less relevant. The copepods must have switched to anaerobic metabolism, as is the case of many aquatic organisms (Vismann 1991, Oeschger \& Storey 1993). Obviously, for $C$. confluens, the survival of sulphidic periods rather depends on the duration of anoxia than on the concentration of sulphide.

\section{Anaerobic capacity and glycogen}

Cletocamptus confluens contains a glycogen level of about 4 and $16 \%$ of total animal dry weight in males and non-gravid females, respectively. The dry weight of the copepods does not only involve the soft tissue, but also the exoskeleton, which results in even higher amounts per visceral tissue dry weight than those determined. Similarly high contents of glycogen (per gram dry weight of soft tissue) have also been reported from bivalves (Oeschger 1990). For C. confluens, as well as for other marine invertebrates (Oeschger 1990, Schöttler et al. 1990), glycogen serves as a major energy source during anaerobiosis, a fact confirmed by the higher depletion during anoxic and sulphidic exposure compared to normoxic starvation. The lower survival of male and egg sac bearing female $C$. confluens is related to their lower tissue glycogen content. Nongravid females contained more than twice the amount of glycogen than males and therefore possessed a higher anaerobic capacity. Under anoxic or anoxic/ sulphidic conditions non-gravid females consumed $\sim 80 \mu \mathrm{mol}$ glycosyl units $\mathrm{g}^{-1} \mathrm{dw} \mathrm{d}^{-1}$. The glycogen content remaining in their tissue after $4 \mathrm{~d}$ of anoxia amounted to $63 \%$ of the initial level and thus was still higher than that of males which were not exposed. The size of the glycogen store of non-gravid females after anoxic exposure did not differ significantly from that of copepods which were exposed to sulphidic anoxia. Therefore, it is obvious that the consequences of each type of stress on the energy metabolism are similar. This is supported by the findings of Oeschger \& Storey (1990) for the priapulid Halicryptus spinulosus (v. Siebold 1849). They suggested that there is no additional effect of sulphide exposure on the glycolytic key regulatory enzymes.

\section{Metabolic rate}

Males and females differ not only in their survival of anoxic and sulphidic conditions and in their amount of tissue glycogen, but also with respect to oxygen consumption at normoxia. Specific oxygen consumption of males lies within the range so far measured for copepods: 100 to $500 \mu \mathrm{mol} \mathrm{g}^{-1} \mathrm{dw} \mathrm{h}^{-1}$ (Lasker et al. 1970 , Vernberg et al. 1977, Hermann \& Heip 1983, Powell 1989). These values are higher than those measured for benthic animals of various size classes: 50 to $100 \mu \mathrm{mol} \mathrm{g}{ }^{-1} \mathrm{dw} \mathrm{h}^{-1}$ (Powell 1989). The oxygen consumption rates of non-gravid females were surprisingly low and did not conform to the above-mentioned range for copepods. A permanently low metabolic rate (under normoxic conditions) would allow for the low demand for ATP to be met by non-oxidative pathways under anoxic conditions. On the other hand, low specific oxygen consumption under normoxic conditions does not necessarily reflect total energy production since anaerobic processes may already contribute to ATP synthesis when oxygen is present (Wieser et al. 1974).

The lower glycogen stores and higher respiration rate of males correspond to their comparatively more active behaviour. Male Cletocamptus confluens use their antennules to clasp a juvenile female during the last copepodid stages for an extended period before transferring spermatophores (K. Vopel unpubl. obs.). This is widespread among podoplean copepods and was interpreted as mate guarding (Boxshall 1990). Carrying a juvenile female presumably represents a selective advantage by increasing its own reproductive success, but also requires additional energy. Males obviously do not need to store energy reserves by reason of their function within the population. Males have to produce spermatophores and mate with sexually receptive females, which probably derive some advantage with respect to energy reserves from being mate guarded. 


\section{Resistance of eggs and development}

During a sulphidic period, eggs are exposed to the same conditions as the adult females carrying them. The experiments showed that nauplii do not hatch from the eggs during anoxic or sulphidic conditions. Hatching takes place after normoxic conditions are restored. No differences in the hatching success between the 3 treatments could be observed. Several studies showed that copepod eggs survive anoxia for days, weeks and in some cases years (Uye \& Fleminger 1976, Ban \& Minoda 1992, Lutz et al. 1992, Marcus et al. 1994). Marcus et al. (1997) compared the impact of anoxia and anoxia/sulphide on the viability of eggs of 3 calanoid copepods using sulphide concentrations ranging from 283 to $352 \mu \mathrm{mol} \mathrm{l}^{-1}$ at a high $\mathrm{pH}$ of 8.1 to 8.7. This study indicated that early stage subitaneous copepod embryos which sink to the sea bed can survive days to weeks in the sediment. The authors also observed no significant differences in the mortality of eggs exposed to anoxia/sulphide compared to anoxia alone.

Since the time for development from nauplius to adult Cletocamptus confluens did not differ in anoxic, sulphidic and normoxic incubations, one may conclude that temporary sulphidic periods occurring in the natural environment do not have a negative impact on naupliar development. Consequently, not only nongravid females, but also the current egg sacs of egg bearing females can be seen to enhance the potential for the survival and persistence of the population during extended sulphidic periods. Even if egg bearing females die as a result of the unfavourable conditions, the eggs remain viable and nauplii hatch after the return of favourable environmental conditions, ensuring restoration of the population.

Differences in the size of glycogen stores within the population depending on sex and developmental stage likely cause variations in life-history traits when populations of Cletocamptus confluens are exposed to prolonged anoxia and high sulphide concentration. Non-gravid females possess a higher capacity for anaerobiosis than males. Obviously, they survive stagnation periods, whereas egg bearing females and males die. Non-gravid females used in our experiments were already inseminated and potentially able to fertilise eggs in the absence of males when favourable conditions were restored. This was shown for Cletocamptus retrogressus Schmankevitch 1875 by Champeau \& Francezon (1991) with respect to summer drying in the brackish marshes of the Camargue, France. The authors suggested that eggs produced by reactivated females did not result from parthenogenetic reproduction. Inactive females that had been inseminated before drying are able to fertilise eggs with spermato- zoa that have remained alive after several months in the genital tract. A similar strategy can be inferred for C. confluens. It seems that non-gravid females and egg sacs represent the potential to build up a new population after long-duration exposures to anoxia and sulphide. This hypothesis needs to be tested in future field and laboratory studies.

Acknowledgements. We especially thank Dr D. Schiedek and A. Schwartinski for their help in analysing glycogen. We are also grateful to Dr D. Abele, Dr E. Foell and 3 anonymous referees for valuable comments on the manuscript. The work was supported by the Bundesministerium für Bildung, Wissenschaft und Technologie (BMBF) under the project DYSMON II (03F0028A0). This is AWI publication No. 1528

\section{LITERATURE CITED}

Bagarinao T (1992) Sulfide as an environmental factor and toxicant: tolerance and adaptations in aquatic organisms Aquat Toxicol 24:21-62

Ban S, Minoda T (1992) Hatching of diapause eggs of Eurytemora affinis (Copepoda: Calanoida) collected from lakebottom sediments. J Crust Biol 12:51-56

Bergmeyer HU (1984) Methoden der enzymatischen Analyse. Verlag Chemie, Weinheim

Boxshall GA (1990) Precopulatory mate guarding in copepods. Bijdr Dierkd 60:209-213

Carman KR, Todaro MA (1996) Influence of polycyclic aromatic hydrocarbons on the meiobenthic-copepod community of a Louisiana salt marsh. J Exp Mar Biol Ecol 198: $37-54$

Carman KR, Fleeger JW, Means JC, Pomarico SM, MCMillin DJ (1995) Experimental investigation of the effects of polynuclear aromatic hydrocarbons on an estuarine sediment food web. J Mar Res 40:289-318

Castel J (1992) The meiofauna of coastal lagoon ecosystems and their importance in the food web. Vie Milieu 42: $125-135$

Champeau A, Francezon P (1991) Laying and fecundity of females of the harpacticoid copepod Cletocamptus retrogressus, Schmankevitch, after their survival of drying. CR Acad Sri Paris t 8 Sér III 312:389-393

Di Pinto I.M1. Coull BC, Chandler GT (1993) Lethal and sublethal effects of the sediment-associated PCB Aroclor 1254 on a meiobenthic copepod. Environ Toxicol Chem 12: $1909-1918$

Escaravage V, Castel J (1990) The impact of the lagoonal shrimp Palaemonetes varians (Leach) on meiofuuna in a temperate coastal impoundment. Acta Oecol 11:409 .418

Gilboa-Garber N (1971) Direct spectrophotometric determination of inorganic sulfide in biological materials and in other complex mixtures. Anal Biochem 43:129-133

Grieshaber MK, Völkel S (1998) Animal adaptations for tolerance and exploitation of poisonous sulfide. Annu Rev Physiol 60:33-54

Grieshaber MK, Hardewig I, Kreutzer U, Pörtner HO (1994) Physiological and metabolic responses to hypoxia in invertebrates. Rev Physiol Biochem Pharmacol 125:43-147

Hansen MH, Ingvorsen K, Jorgensen BB (1978) Mechanisms of hydrogen sulfide release from coastal marine sediments to the atmosphere. Limnol Oceanogr 23:68-76

Herman PMJ, Heip C (1983) The respiration of five brackish water harpacticoid copepod species. J Exp Mar Biol Ecol $71: 249-256$ 
Holter H (1943) Technique of the cartesian diver. CR Trav Lab Carlsberg 24:399-478

Jahn A, Gamenick I, Theede H (1996) Physiological adaptations of Cyprideis torosa (Crustacea, Ostracoda) to hydrogen sulphide. Mar Ecol Prog Ser 142:215-223

Jergensen BB, Revsbech NP, Blackburn TH, Cohen. Y (1979) Diurnal cycle of oxygen and sulfide microgradients and microbial photosynthesis in a cyanobacterial mal sediment. Appl Environ Microbiol 38:46-58

Klekowski RZ (1971) Cartesian diver microrespirometry for aquatic animals. Pol Arch Hydrobiol 18:93-114

Lasker. R, Wells JBJ, McIntyre AD (1970) Growth, reproduction, respiration and carbon utilization of the sanddwelling harpacticoid copepod, Asellopsis intermedia. J Mar Biol Assoc UK 50:147-160

Lasserre P, Renaud-Mornant J, Castel J (1975) Metabolic activities of meiofaunal communities in a semi-enclosed lagoon. Possibilities of trophic competition between meiofauna and mugilid fish. Proc 10th Eur Mar Biol Symp 2: $393-414$

Lutz RV, Marcus NH, Chanton JP (1992) Effects of low oxygen concentrations on the hatching and viability of eggs of marine calanoid copepods. Mar Biol 114:241-247

Marcus NH, Lutz RV, Burnett W, Cable P (1994) Age, viability, and vertical distribution of zooplankton resting eggs from an anoxic basin: evidence of an egg bank. Limnol Oceanogr 39:154-158

Marcus NH, Lutz RV, Chanton JP (1997) Impact of anoxia and sulphide on the viability of eggs of three planktonic copepods. Mar Ecol Prog Ser 146:291-295

Naess T (1991) Ontogenetic and sex dependent rotenone tolerance of a marine copepod. Acartia clausi Giesbrecht. Sarsia 76:29-32

National Research Council (1979) Hydrogen sulfide. University Park Press, Baltimore

Oeschger R (1990) Long-term anaerobiosis in sublittoral marine invertebrates from the Western Baltic Sea: Halicryptus spinulosus (Priapulida), Astarte borealis and Arctica islandica (Bivalvia). Mar Ecol Prog Ser 59:133-143

Oeschger R, Storey KB (1990) Regulation of glycolytic enzymes in the marine invertebrate Halicryptus spinulosus (Priapulida) during environmental anoxia and exposure to hydrogen sulfide. Mar Biol 106:261-266

Oeschger R, Storey KB (1993) Impact of anoxia and hydrogen sulphide on the metabolism of Arctica islandica L. (Bivalvia). J Exp Mar Biol Ecol 170:213-226

Powell E (1989) Oxygen, sulfide and diffusion: why thiobiotic

Editorial responsibility: Otto Kinne (Editor),

Oldendorf/Luhe, Germany meiofauna must be sulfide-insensitive first-order respirers. J Mar Res 47:887-932

Revsbech NP, Jorgensen BB, Blackburn TH, Cohen Y (1983) Microelectrode studies of the photosynthesis and $\mathrm{O}_{2}, \mathrm{H}_{2} \mathrm{~S}$ and $\mathrm{pH}$ profiles of a microbial mat. Limnol Oceanogr 28: $1062-1074$

Sachs L (1992) Angewandte Statistik: Anwendung statistischer Methoden. Springer, Berlin

Schäfer HW (1936) Harpacticoiden aus dem Brackwasser der Insel Hiddensee. Zool Jb (Systematik) 68:445-588

Schöttler U, Daniels D, Zapf K (1990) Influence of anoxia on adaptation of euryhaline polychaetes to hyposmotic conditions. Mar Biol 104:433-451

Somero GN, Childress JJ, Anderson AE (1989) Transport, metabolism, and detoxification of hydrogen sulfide in animals from sulfide-rich marine environments. CRC Crit Rev Aquat Sci 1:591-614

Tinson S, Laybourn Parry J (1985) The behavioural response and tolerance of freshwater benthic cyclopoids to hypoxia and anoxia. Hydrobiologia 127:257-263

Uye S, Fleminger A (1976) Effects of various environmental factors on egg development of several species of Acartia in southern (ictlifornia. Mar Biol 3:253-262

Vernberg WB, Coull BC, Jorgensen DD (1977) Reliability of laboratory metabolic measurements of meiofauna. J Fish Res Bd Can 34:164-167

Vetter RD, Powell MA, Somero GN (1991) Metazoan adaptations to hydrogen sulphide. In: Bryant C (ed) Metazoan life without oxygen. Chapman and Hall, London, p 109-128

Vismann B (1991) Sulfide tolerance: physiological mechanisms and ecological implications. Ophelia 34:1-27

Völkel S, Grieshaber MK (1992) Mechanisms of sulphide tolerance in the peanut worm, Sipunculus nudus (Sipunculidae), and in the lugworm, Arenicola marina (Polychaeta). J Comp Physiol B 162:469-477

Völkel S, Grieshaber MK (1994) Oxygen dependent sulfide detoxification in the lugworm Arenicola marina. Mar Biol 118:137-147

Vopel K, Dehmlow J, A,rlt G (1996) Vertical distribution of Cletocamptus confluens (Copepoda, Harpacticoida) in relation to oxygen and sulphide microprofiles of a brackish water sulphuretum. Mar Ecol Prog Ser 141:129-137

Wieser W, Ott J, Schiemer F, Gnaiger E (1974) An ecophysiological study of some meiofauna species inhabiting a sandy beach at Bermuda. Mar Biol 26:235-248

Zeuthen E (1950) Cartesian diver respirometer. Biol Bull 98 : $139-143$

Submitted: June 11, 1998; Accepted: August 27, 1998

Proofs received from author(s): November 18, 1998 